\title{
Pimpinella alpina Molk Administration is Capable of Increasing Antioxidant and Decreasing Prooxidant Level following UVB Irradiation
}

\author{
Taufiqurrachman Nasihun $^{1 *}$ and Eni Widayati ${ }^{2}$ \\ 'Department of Biochemistry, Faculty of Medicine, Sultan Agung Islamic University, Semarang, Indonesia; \\ taufiq_rn@yahoo.com \\ ${ }^{2}$ Department of Chemistry, Faculty of Medicine, Sultan Agung Islamic University, Semarang, Indonesia
}

\begin{abstract}
Introduction: Indonesian male population has traditionally used Pimpinella alpina Molk ( $\mathrm{PaM}$ ) to prevent degenerative disease. However, the scientific evidence of PaM effect on increase in antioxidant and decrease in prooxidant level and their negative correlation remains unclear. Objective: To prove the effect of PaM on increase in antioxidant and decrease in prooxidant and their negative correlation following Ultraviolet B (UVB) exposed repeatedly. Methods: Forty male rats were assigned into 8 groups, treatment groups for 7 days: PaM 50 mg (PaM50-7), PaM 100 mg (PaM100-7), PaM 150 mg (PaM150-7), and for 15 days: PaM 100 mg (PaM100-15), PaM 150 mg (PaM150-15). The increase in antoxidant and decrease in prooxidant levels were measured by ELISA and Spectophotometer. Results: Statistical analysis indicated that antioxidant Catalase (CAT) and Super Oxyde Dismutase (SOD) activities in PaM groups were significantly higher, $\mathrm{p}<0.001$. In contrary, prooxidant levels marked by Malondialdehide (MDA) and 8-hydroxy-2-deoxyguanosine (8OHdG) concentrations in PaM groups were significantly lower, $p<0.001$. There was also a negative correlation between antioxidant and prooxidant levels, $p<0.001$. Conclusion: PaM administration with 50-150 mg daily dosage for 7-15 days capable of increasing antioxidant and decreasing Prooxidant levels, with a negative correlation following UVB irradiation repeatedly.
\end{abstract}

Keyword: Oxidative stress, Pimpinella alpina Molk, CAT, MDA, SOD, 8OHdG

\section{Introduction}

The number of aged population ( $>60$ yrs old) increase significantly in some regions of the world ${ }^{1-3}$. The increase in aged population as predicted will continuously occur in the next decade. Consequently, the number of aged population is larger compared to young adult population ${ }^{1,2,4}$. Unfortunately, $20 \%$ of the aged left-over life is accompanied with frailty and worsen quality of life due to chronic degenerative diseases ${ }^{5}$. Degenerative disease is tightly associated with cellular oxidative stress $^{6,7}$, defined as an imbalance between oxidants
(ROS) and the antioxidant defense ${ }^{8}$. Pimpinella alpina Molk (PaM) (Apiaceae), in Indonesia is known as Purwoceng, is a medicinal plant growing in Dieng plateau Central Java that have traditionally utilized as rejuvenation remedy for male of 40 yrs old or above ${ }^{9}$. It is very relevant, since $60 \%$ of aged populations who suffer from degenerative diseases are males. However, the scientific evidence of PaM effects on activity of Superoxide Dismutase (SOD) and Catalase (CAT), and Malondialdehide (MDA), as well as 8-hydroxy-2deoxyguanosine (8OhdG), and their negative correlation are not yet investigated. 
Ultraviolet B (UVB; 290-320 nm) is a component of solar UV, which continuously exposes to normal human skin causing various adverse effects such as photo aging and skin cancer ${ }^{10,11}$. These adverse effects were mostly attributable to increase in production of Reactive Oxygen Species (ROS) and alteration of antioxidant defensive system leading to cellular oxidative stress. The most abundant ROS generated by UVB in the skin is hydroxyl radical $\left(\mathrm{OH}^{\bullet}\right)$ and singlet oxygen $\left({ }^{1} \mathrm{O}_{2}\right)$. Hydroxyl radical results from water degradation, whilst ${ }^{1} \mathrm{O}_{2}$ gets generated from the existing endogenous photosensitizer such as riboflavin, linoleic acid, linolenic acid and arachidonic $\operatorname{acid}^{12}$. Another ROS which is also produced in skin are hydrogen peroxide $\left(\mathrm{H}_{2} \mathrm{O}_{2}\right)$ and oxygen superoxide $\left(\mathrm{O}_{2}{ }^{-}\right)$. They are produced from mitochondrial oxidative phosphorilation, triggered by UVB irradiation ${ }^{13}$. According to various evidences, the most dangerous ROS in the body is $\mathrm{OH}^{\circ}, \mathrm{O}_{2}^{-}$, and ${ }^{1} \mathrm{O}_{2}$. Hydroxyl radical has wide capacity to react with protein, nucleic acid, Polyunsaturated Fatty Acid (PUFA), and other molecules. Consequently, $\mathrm{OH}^{*}$ is able to cause the tremendous alteration in cellular structures and damages ${ }^{14}$. On the other hand, $\mathrm{O}_{2}^{-},{ }^{1} \mathrm{O}_{2}$ are able to liberate $\mathrm{Fe}^{2+}$ from ferritin, lactoferin, and transferrin, subsequently induced Fenton reaction to form $\mathrm{OH}^{*}$ which in turn induces further cellular damages ${ }^{14}$. UVB irradiation on cells generates Malondihaldehide (MDA), resulting from reaction the between $\mathrm{OH}^{*}$ and PUFA particularly arachidonic acid of cellular membrane. In addition, UVB radiation also result in several types of DNA damage such as the formation of Cyclobutane Pyrimidine Dimers (CPDs), pyrimidine (6-4) pyrimidonephotodimers, and 8-hydroxy-2deoxyguanosine (8-OHdG) in both nuclear DNA (nDNA) and mitochondrial DNA (mtDNA) ${ }^{10,15,16}$. Both cellular membrane and DNA bases damages leads degenerative diseases ${ }^{17}$. Considering that degenerative disease is mainly caused by cellular damage, therefore it can be prevented and modified by consumption of natural antioxidant ${ }^{18,19}$.

In addition to stigmasterol (phytoandrogen), another significant constituent of $\mathrm{PaM}$ is flavonoids ${ }^{20}$, a potent natural antioxidant, radical scavenger, and metal ion chelator agent ${ }^{21}$. There are tremendous evidences that flavonoids have an important biological role as antioxidant which are capable of inhibiting ROS production through suppression of ROS formation. Suppression of ROS formation can be performed either by inhibition of enzymes or by chelating trace elements involved in free radical generation. Another action of antioxidant flavonoids to reduce ROS concentration is through scavenging ROS, and up regulation of antioxidant defenses ${ }^{22,23}$. Decrease in ROS formation, followed by increase in activity of enzymatic antioxidant defenses such as SOD and CAT, leading to pro-oxidant antioxidant balance, providing the cellular damages due to oxidative stress an opportunity to undertake denovo formation for self-repair. Flavonoids have also been proven capable of scavenging free radical superoxide anion $\left(\mathrm{O}_{2}^{-}\right)$and peroxynitrit anion $\left(\mathrm{ONOO}^{-}\right)$, resulting in increase in Nitric Oxide (NO) that beneficial for vascular dilation ${ }^{24}$. The scavenging effect of flavonoids on ROS and RNS are significantly determined by the B ring of hydroxyl number and configuration. Flavonoids which possess a lot of hydroxyl groups and variety of configuration easily donates hydrogen and an electron to hydroxyl, peroxyl, and peroxynitrite radicals, stabilizing them and giving rise to a relatively stable flavonoids radical ${ }^{21,25}$. These above-mentioned details imply that PaM have a capacity to prevent cell senescent and degenerative diseases through two mechanisms that complement each other e.g. androgen replacement therapy and oxidative stress prevention.

Based on the overall facts, the purpose of the present study was to prove the effect of PaM administration on SOD and CAT activity increment, otherwise decrease in concentration of MDA and $8 \mathrm{OHdG}$, and their negative correlation after UVB irradiation.

\section{Methods}

In this experimental study, the post test with only control group was adopted as design research. Forty Sprague Dawley (SD) male rats, 6 months old, and \pm 300 gram Body Weight (BW), were assigned into 8 groups randomly as follow: 1. Normal group (Nor-G), rats neither got UVB irradiation nor PaM treatment. 2. Negative control group for seven days (Neg-7) and 15 days (Neg-15), rats in both groups got UVB irradiation only 7 days. 3 . PaM treatment group, was divided into two arms: First arm comprise three groups: PaM50-7, PaM100-7, and PaM150-7, in these groups all rats were radiated with UVB and treated with PaM $50 \mathrm{mg}, 100 \mathrm{mg}$, and $150 \mathrm{mg}$ doses per day respectively during 7 days; Second arm 
comprise 2 groups: PaM100-15, and PaM150-15, all rats in these groups were exposure to UVB for 7 days and administered PaM with dose of $100 \mathrm{mg}$ and $150 \mathrm{mg}$ respectively during 15 days. The seven days duration was proposed to provide cell an opportunity to undertake denovo formation for repairing. All rats were kept in acclimatization for one week with environmental controlled temperature $\left(20^{\circ} \mathrm{C}-24^{\circ} \mathrm{C}\right)$, constant humidity (55-60\%), and controlled photoperiod (12 h light and $12 \mathrm{~h}$ dark) properties before beginning of experiment. During the study all rats in all groups were given standard dietary (Ain 93) intake and tap water adlibitum. Blood samples from rats in Nor-G, Neg-7, PaM50-7, PaM1007, and PaM150-7 were taken at day 8 of study, and the activity of SOD and CAT, and the concentration of MDA and $8 \mathrm{OHdG}$ were measured. Meanwhile, at day 16 with the similar method, blood samples from rats in Neg-15, PaM100-15, and PaM150-15 were taken for assessing the same variables. All measurement of variables was undertaken at Inter University Program (PAU) of Gajah Mada University (UGM) Yogyakarta Indonesia. The present study has been approved by the ethical committee of Sultan Agung Islamic University Medical faculty, Semarang Central Java, Indonesia.

\subsection{PaM Extract}

Pimpinella alpina Molk was obtained from Dieng Plateu Central Java and extracted by Soxhlet method from the whole plant with ethanol as a solvent. PaM was crushed using a pestle and mortar until homogenous to provide a greater surface area. The process was run for a total of 16 hours. Ethanol was desolvated by using a rotary evaporator, leaving a small yield of extracted plant material in the glass bottom flask.

\subsection{UVB Irradiation}

UVB radiation was delivered using UV light sources fluorescent sun lamp FS72T12-UVB-H emitting a UVB wave length ranging from $280-320 \mathrm{~nm}$, with a peak of $312.5 \mathrm{~nm}$ at the distance of $25 \mathrm{~cm}$, was measured from cage floor. The average flux intensity at cage floor measured with digital UV light meter YK-35UV was $9.3 \mathrm{j} / \mathrm{m}^{2} / \mathrm{sec}$. Hairless rats in all groups except in Nor-G were placed in plastic cage exposed to $1.6 \mathrm{~kJ}$ per $\mathrm{M}^{2}$ or equivalent to Minimal Erythematic Dose (MED) for 30 minutes per day for seven days.

\subsection{Assessment of SOD}

The blood was hemolyzed with ice-cold water. Hemoglobin was removed by adding chloroform and ethanol followed by centrifugation. The clear supernatant was used for the SOD assay. The absorbance change at $560 \mathrm{~nm}$ was monitored at $25^{\circ} \mathrm{C}$ for $20 \mathrm{mins}^{26}$. Enzyme activity was expressed as Units/mL of blood.

\subsection{Assessment of CAT}

The rate of decomposition of $\mathrm{H}_{2} \mathrm{O}_{2}$ by CAT was measured spectrophotometrically at $230 \mathrm{~nm}$. Ethanol was added to stabilize the haemolysate by breaking down 'complex II' of catalase and $\mathrm{H}_{2} \mathrm{O}_{2}$. After the addition of $50 \mathrm{ml}$ Tris buffer, $900 \mathrm{ml}$ of $\mathrm{H}_{2} \mathrm{O}_{2}$ and $30 \mathrm{ml}$ of $\mathrm{H}_{2} \mathrm{O}$ to the cuvettes, the system was incubated at $37^{\circ} \mathrm{C}$ for $10 \mathrm{~min}$, the haemolysate was added, and, in the next $10 \mathrm{~min}$, the decrease of optical density is measured against blank at $412 \mathrm{~nm}$.

\subsection{Assessment of MDA}

One milliliter of TBA reagent (15\% v/v trichloroacetic acid and $0.25 \mathrm{~N} \mathrm{HCl}$ ) was mixed with $500 \mathrm{ml}$ of supernatant and was treated in a boiling water bath for $15 \mathrm{~min}$. After cooling, the preparation was centrifuged at $1000 \mathrm{~g}$ for $10 \mathrm{~min}$. The supernatant was then removed, and absorbance of the samples was measured at $532 \mathrm{~nm}$. The MDA concentration was expressed as nmol MDA/mg protein.

\subsection{Assessment of $80 \mathrm{HdG}$}

Concentration of $8-\mathrm{OHdG}$ in serum was measured by a competitive in vitro ELISA kit. ELISA kit (Abcam), contains a monoclonal antibody specific for 8-OhdG. The determination principle of this method is to compare the quantity of $8-\mathrm{OHdG}$ in unknown sample with its absorbance of a known 8-OHdG standard curve. The unknown 8-OHdG samples or 8-OhdG standards are first added to an $8-\mathrm{OHdG} / \mathrm{BSA}$ conjugate preabsorbed ELISA plate. After a brief incubation, an anti 8-OHdG monoclonal antibody was added, followed by a Horseradish Peroxides (HRP) conjugated secondary antibody. ELISA was carried out in triplicate and in a blinded fashion, and the average value was used for statistical analyses. The kit has an 8 -OHdG detection sensitive range of $0.94 \mathrm{ng} / \mathrm{ml}-60 \mathrm{ng} / \mathrm{ml}$. The procedure was carried out according to manufacturer's instructions. 


\subsection{Statistical Analysis}

Results are presented as mean $\pm \mathrm{SD}$; the differences between means in each group were assessed by Anova and Post Hoc multiple comparison test. All statistical analysis was performed using computer methods. The significance level was set for $P<0.05$.

\section{Results}

Sprague male rats were obtained from PAU Gajah Mada University varies ranging from 225 grams - 334 grams; therefore, need to be equalized with multistage random sampling allocation. Accordingly, all rats could be allocated in 8 groups, 5 rats of each with comparable mean body weight; thereby the dosage of PaM could be delivered appropriately in each group. At day 8 and 16 following PaM treatment all variables comprising activity of CAT and SOD, and concentration of MDA and $8 \mathrm{OHdG}$ were measured and the results are shown in Table 1.

This result indicated that the highest activity of SOD and CAT were occurred in Nor-G, followed by PaM15015, PaM100-15, PaM150-7, PaM100-7, PaM50-7, NeG-7, and the lowest was in Neg-15. In contrary the lowest level of MDA and $8 \mathrm{OHdG}$ were found in Nor-G, followed by PaM150-15, PaM100-15, PaM150-7, PaM100-7, PaM507, Neg-7, and the highest was in Neg-15 (Table 1). Anova statistical analysis pointed out that there were significant differences among groups, $\mathrm{p}<0.001$.

\subsection{Concentration of MDA and 8OHdG}

Post Hoc LSD statistical analysis showed that concentration of MDA and $8 \mathrm{OHdG}$ in Neg-7 and Neg-15 were significantly higher compared with those of Nor-G, $p<0.001$. The concentration of MDA and 8OHdG in PaM50-7, PaM100-7, and PaM150-7 were lower significantly compared to those of Neg-7 and Neg-15, $p<0.001$, but higher significantly compared to those of Nor-G, $\mathrm{p}<0.001$. Furthermore, concentration of MDA and 8OHdG in PaM100-15 and PaM150-15, were significant lower compared to those of PaM50-7, PaM100-7, and PaM150-7, $\mathrm{p}<0.001$ respectively. Specifically, for the concentration of $8 \mathrm{OHdG}$ in PaM15015 was higher compared to that of Nor-G, but that difference was not significant, $\mathrm{p}=0.579$ (Figure 1).

Tabel 1: Body weight, CAT activity, SOD activity, MDA concentration, and 8OHdG concentration in Sprague Dawley male rats following PaM reatment and UVB irradiation

\begin{tabular}{|c|c|c|c|c|c|c|c|c|c|}
\hline \multirow[b]{2}{*}{ Variables } & \multicolumn{8}{|c|}{ Groups } & \multirow[b]{2}{*}{$\begin{array}{c}P \\
\text { (anova }\end{array}$} \\
\hline & $\begin{array}{l}\text { Nor-G } \\
(n=5)\end{array}$ & $\begin{array}{l}\text { Neg-7 } \\
(n=5)\end{array}$ & $\begin{array}{c}\text { Neg-15 } \\
(n=5)\end{array}$ & $\begin{array}{l}\mathrm{PaM} \\
50-7 \\
(n=5)\end{array}$ & $\begin{array}{l}\mathrm{PaM} \\
100-7 \\
(n=5)\end{array}$ & $\begin{array}{l}\text { PaM } \\
150-7 \\
(n=5)\end{array}$ & $\begin{array}{c}\text { PaM } \\
100-15 \\
(n=5)\end{array}$ & $\begin{array}{c}\text { PaM } \\
150-15 \\
(n=5)\end{array}$ & \\
\hline $\begin{array}{l}\text { BW } \\
\text { Gram } \\
( \pm S D)\end{array}$ & $\begin{array}{c}267.78 \\
( \pm 25.20)\end{array}$ & $\begin{array}{c}268.64 \\
( \pm 28.03)\end{array}$ & $\begin{array}{c}268.65 \\
( \pm 28.53)\end{array}$ & $\begin{array}{c}266.42 \\
( \pm 19.55)\end{array}$ & $\begin{array}{c}267.78 \\
( \pm 19.55)\end{array}$ & $\begin{array}{c}270.65 \\
( \pm 20.20)\end{array}$ & $\begin{array}{c}2.69 .43 \\
( \pm 28.03)\end{array}$ & $\begin{array}{c}267.69 \\
( \pm 28.53)\end{array}$ & 0.950 \\
\hline $\begin{array}{l}\text { CAT } \\
\mathrm{U} / \mathrm{ml} \\
( \pm \mathrm{SD})\end{array}$ & $\begin{array}{c}2.13 \\
( \pm 0.03)\end{array}$ & $\begin{array}{c}0.88 \\
( \pm 0.01)\end{array}$ & $\begin{array}{c}0.73 \\
( \pm 0.03)\end{array}$ & $\begin{array}{c}0.97 \\
( \pm 0.01)\end{array}$ & $\begin{array}{c}1.05 \\
( \pm 0.03)\end{array}$ & $\begin{array}{c}1.28 \\
( \pm 0.03)\end{array}$ & $\begin{array}{c}1.40 \\
( \pm 0.03)\end{array}$ & $\begin{array}{c}1.80 \\
( \pm 0.05)\end{array}$ & 0.000 \\
\hline $\begin{array}{l}\mathrm{SOD} \\
\mathrm{U} / \mathrm{ml} \\
( \pm \mathrm{SD})\end{array}$ & $\begin{array}{l}306.61 \\
( \pm 5.23)\end{array}$ & $\begin{array}{l}91.35 \\
( \pm 4.20)\end{array}$ & $\begin{array}{c}76.77 \\
( \pm 5.94)\end{array}$ & $\begin{array}{l}108.30 \\
( \pm 7.54)\end{array}$ & $\begin{array}{l}149.83 \\
( \pm 8.67)\end{array}$ & $\begin{array}{l}180.68 \\
( \pm 5.24)\end{array}$ & $\begin{array}{l}197.29 \\
( \pm 6.62)\end{array}$ & $\begin{array}{l}292.38 \\
( \pm 3.54)\end{array}$ & 0.000 \\
\hline $\begin{array}{l}\text { MDA } \\
\mathrm{nmol} / \mathrm{ml} \\
( \pm S D)\end{array}$ & $\begin{array}{c}1.02 \\
( \pm 0.09)\end{array}$ & $\begin{array}{c}4.60 \\
( \pm 0.13)\end{array}$ & $\begin{array}{c}5.21 \\
( \pm 0.16)\end{array}$ & $\begin{array}{c}3.95 \\
( \pm 0.25)\end{array}$ & $\begin{array}{c}2.74 \\
( \pm 0.24)\end{array}$ & $\begin{array}{c}2.19 \\
( \pm 0.15)\end{array}$ & $\begin{array}{c}2.20 \\
( \pm 0.10)\end{array}$ & $\begin{array}{c}1.55 \\
( \pm 0.17)\end{array}$ & 0.000 \\
\hline $\begin{array}{l}8 \mathrm{OHdG} \\
\mathrm{Ng} / \mathrm{ml} \\
( \pm \mathrm{SD})\end{array}$ & $\begin{array}{c}3.50 \\
( \pm 0.25)\end{array}$ & $\begin{array}{c}10.08 \\
( \pm 0.23)\end{array}$ & $\begin{array}{c}12.36 \\
( \pm 0.48)\end{array}$ & $\begin{array}{c}8.94 \\
( \pm 0.23)\end{array}$ & $\begin{array}{c}7.26 \\
( \pm 0.33)\end{array}$ & $\begin{array}{c}5.50 \\
( \pm 0.15)\end{array}$ & $\begin{array}{c}4.22 \\
( \pm 0.29)\end{array}$ & $\begin{array}{c}3.62 \\
( \pm 0.52)\end{array}$ & 0.000 \\
\hline
\end{tabular}




\subsection{Activity of SOD and CAT}

Both SOD and CAT in Neg-7 and Neg-15, were lower significantly compared with those of Nor-G, $p<0.001$. The activity of SOD and CAT in PaM50-7, PaM100-7, and PaM150-7 were significantly higher compared with those of Neg-7 and Neg-15, p $<0.001$, but significantly lower when compared to those of Nor-G, $p<0.001$. Meanwhile, the activity of SOD and CAT among treatment groups: PaM50-7, PaM100-7, and PaM1507, the highest was found in PaM150-7. However, when compared with PaM100-15 and PaM150-15, activity of SOD and CAT in PaM50-7, PaM100-7, and PaM1507 were significant lower, $\mathrm{p}<0.001$ respectively (Figure 1).

\subsection{Correlation between Oxidant and Antioxidant}

Correlation test between activity of SOD and concentration of MDA as well as SOD and $8 \mathrm{OHdG}$ with Pearson methods on each group displayed that there was a strong negative correlation $(-0.931$ and -0.913 ; $\mathrm{p}<$ $0.001)$ respectively. Likewise, to the activity of CAT and concentration of MDA also CAT activity and 8OHdG concentration, showed negative strong correlation $(-0.908,-0.889 ; \mathrm{p}<0.001)$ respectively. On the other hand, a strong positive correlation between activity of SOD and CAT also occur $(0.981, \mathrm{p}<0.001)$. Likewise, the strong positive correlation $(0.969 ; \mathrm{p}<0.001)$ also occur between concentration of MDA and $8 \mathrm{OHdG}$ (Figure 2).

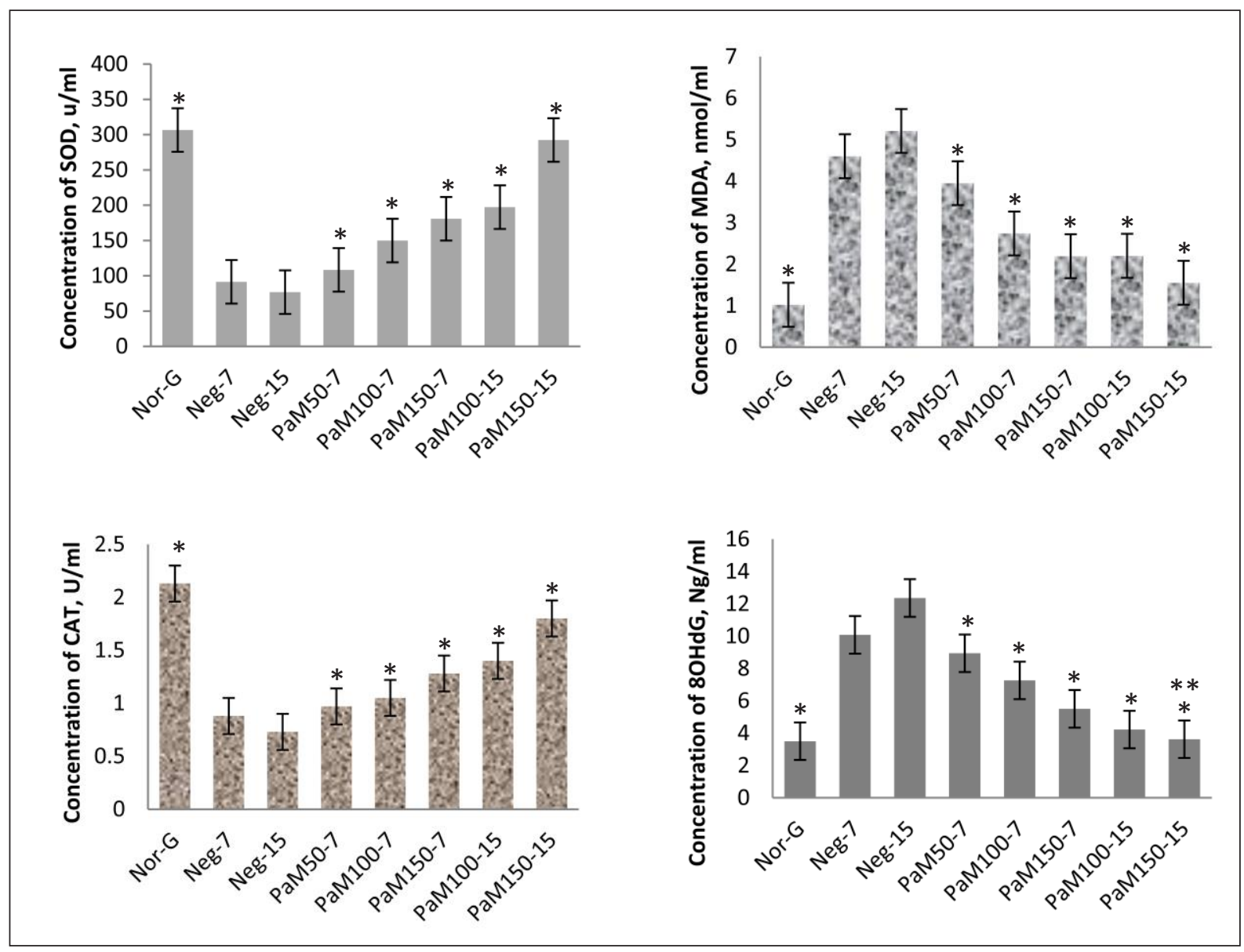

Fig. 1. Activity of superoxydedismuatase (SOD), Catalase (CAT), Concentration of Malondialdehyde (MDA), and 8-hydroxy-2- deoxyguanosine(8OHdG) following UVB radiation and PaM adminstration. Post Hoc Test: ${ }^{*} p<0.005$ Neg-7 and Neg-15 as control; ${ }^{* *} p>0.005$, Nor-G as a control. 


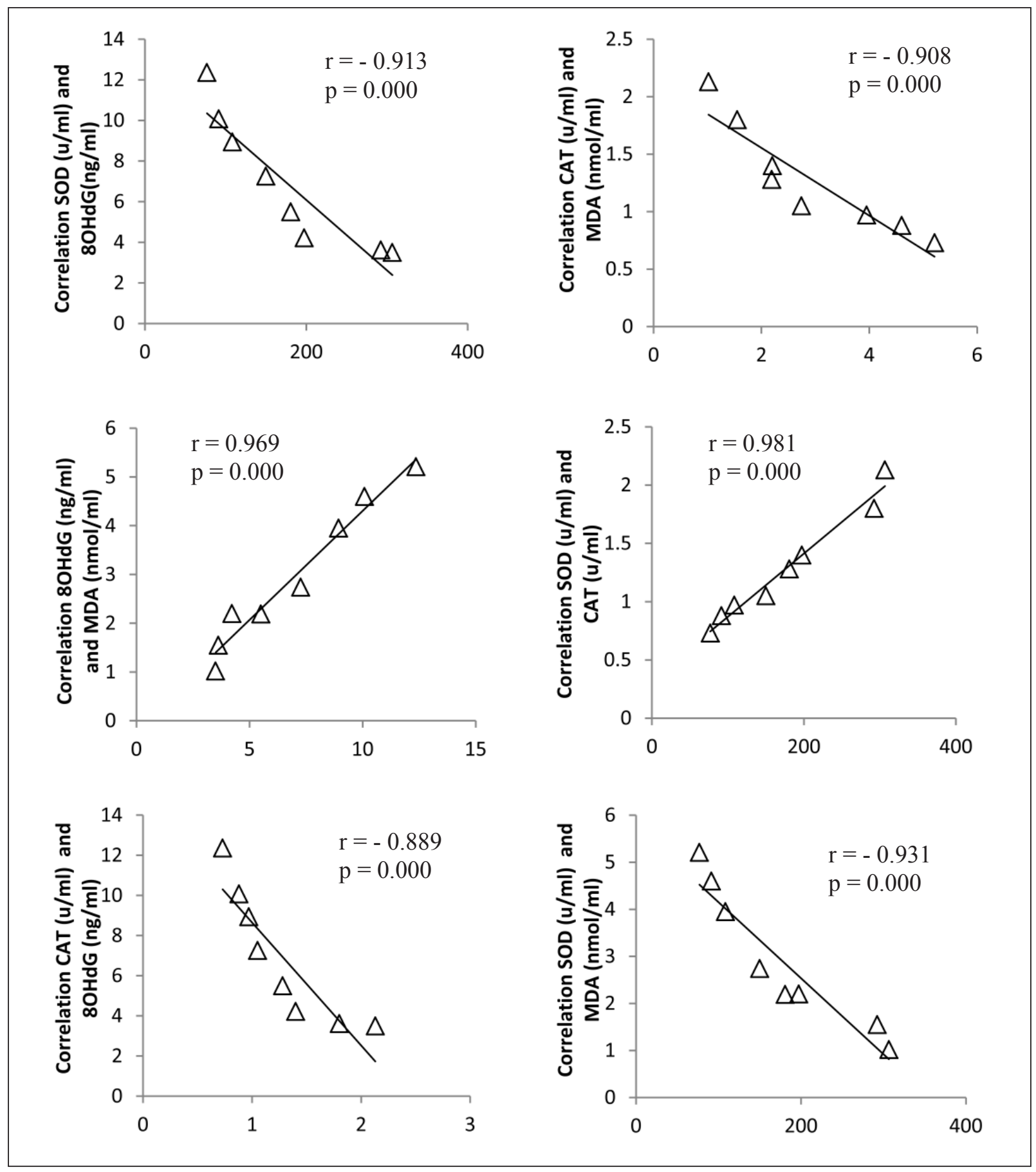

Fig. 2. Correlation analysis between concentration of antioxidant and pro-oxidant in Sprague Dawley male rats after UVB radiation

\section{Discussion}

The result of the present study indicated that concentration of MDA and $8 \mathrm{OHdG}$ in negative control groups were higher compared to those of normal group.
MDA and $8 \mathrm{OHdG}$ are substances that are generated from cellular membrane and DNA respectively following UVB irradiation mediated by ROS. Therefore the increase in concentration of MDA and $8 \mathrm{OHdG}$ reflected that UVB irradiation with $1,6 \mathrm{~kJ} / \mathrm{M}^{2}$ is equivalent to Minimal 
Erythematicdose (MED), for 30 minutes in the distance of $25 \mathrm{~cm}$, worked appropriately to induce pro-oxidant in favor.

This result is in accordance with the numerous previous reports that UVB irradiation was able to increase concentration of ROS including ${ }^{1} \mathrm{O}_{2}, \mathrm{OH}^{*}, \mathrm{O}_{2}^{-}$, and $\mathrm{H}_{2} \mathrm{O}_{2}{ }^{27-29}$. Moreover, Halliwell and Aruoma, 1993, reported that exposure to UVB was able to increase concentration of $\mathrm{OH}^{\cdot}$ and ${ }^{1} \mathrm{O}_{2}$ followed by increase in formation of $8 \mathrm{OHdG}^{30}$. Another study was reported by Chang et al. also demonstrated a similar result that UVB irradiation is able to increase $\mathrm{H}_{2} \mathrm{O}_{2}$ concentration ${ }^{13}$. Numerous previous studies both in vivo and in vitro also demonstrated that UVB irradiation were able to increase the concentration of ${ }^{1} \mathrm{O}_{2}, \mathrm{OH}^{\bullet}, \mathrm{O}_{2}^{-}$, and $\mathrm{H}_{2} \mathrm{O}_{2}$. Although $\mathrm{H}_{2} \mathrm{O}_{2}$ by definition is not a free radical, however, because of its low charged state and non-ionized and its capability of generating $\mathrm{OH}^{\bullet}$ through Fenton reaction, hence $\mathrm{H}_{2} \mathrm{O}_{2}$ is biologically an important and dangerous oxidant ${ }^{13,31}$. Production of ${ }^{1} \mathrm{O}_{2}, \mathrm{OH}^{*}, \mathrm{O}_{2}{ }^{-}$, and $\mathrm{H}_{2} \mathrm{O}_{2}$ were increased in dose dependent manner. It was supported by study reported by Santos AL in which irradiation with UVA, UVB, or UVC on bacteria increased in ROS production and DNA double strand breaks was occurred in dose dependent trend ${ }^{32}$.

On the other hand, in the present study activities of both SOD and CAT in negative control groups were lower significantly compared to those of normal group. These results demonstrated that UVB irradiation on rats, besides increasing concentration of MDA and 8OHdG as described above, also immediately followed by decreasing activity of SOD and CAT. Previous report pointed out that UVB irradiation induced oxidative stress came along with accelerating Lipid Peroxidation (LPO), augmented MDA concentration, and reducing the activity of SOD and $\mathrm{CAT}^{33}$. In vivo study was reported by Cejkova 2000, also demonstrated that UVB irradiation to the corneal rabbit five minutes per day in the distance of $30 \mathrm{~cm}$ for 8 days resulted in the disappearance of CAT and SOD in the flat corneal epithelium. Moreover, UVB irradiation procedure during 8 days, SOD activity was also absent at the corneal periphery. This was in contrast to CAT activity, which was already absent in the limbal region after the 4 days UVB irradiation procedure ${ }^{34}$. The decrease in SOD and CAT following UVB irradiation is probably induced by reducing GSH/GSSG ratio ${ }^{35}$.
Numerous studies have reported that when, either depletion of antioxidants or accumulation of ROS (pro-oxidant and antioxidant imbalance) occur, cells attempt to counteract the pro-oxidant effect and restore the red-ox balance by activation or silencing of genes encoding defensive enzymes, transcription factors, and structural proteins ${ }^{14,36}$.

The increase in MDA and 8OHdG levels after UVB irradiation is not just in dose dependent manner but also determined by the time of exposure, albeit it is not truly linear instead of biphasic. The result of the present study exhibited that the concentration of MDA and $80 \mathrm{OHdG}$ in negative control for 15 days when compared to those of negative control for 7 days were significantly higher. Conversely, both SOD and CAT activities in negative control for 15 days were significant lower compared to those of negative control for 7 days. This result suggested that; albeit UVB irradiation was halted in day 7, the production of ROS and otherwise suppression of both antioxidant SOD and CAT activities in rat were remain continuously occurred until day 15 . Subsequently, the oxidative stress and cellular damages occurrences also has taken place. In the certain extent, this result is supported by numerous studies, demonstrating that activities of SOD, CAT, glutathione reductase, ubiquinol, and Alfa tocopherol were reduced after a single UVB irradiation. However, when exposure to UVB was prolonged for more than 12 weeks, the activity of SOD was also raised ${ }^{37}$.

The increment of MDA concentration following UVB irradiation is a metabolite resulted from reaction between $\mathrm{OH}^{\bullet}$ and unsaturated fatty acid membrane mediated by peroxyl radical (ROO). ROO is a chemical substance constituting a final result of chain reaction between $\mathrm{OH}^{\bullet}$ and unsaturated fatty acid, further propagates chain reaction in lipids, which in turn is reacted back with unsaturated fatty acid membrane to form $\mathrm{MDA}^{38}$. Therefore, antioxidants which are capable of scavenging peroxyl radicals could prevent lipid peroxidation. Another metabolite which is induced by $\mathrm{OH}$ • or other ROS in the body is $8 \mathrm{OHdG}$. However, this $8 \mathrm{OHdG}$ is not derived from reaction between $\mathrm{OH}^{*}$ and unsaturated fatty acid membrane instead of guanine residue of cellular DNA ${ }^{39}$. Afterwards; both MDA and $8 \mathrm{OHdG}$ are accumulated overtime and therefore reflect the increase in concentration of oxidant status and oxidative stress in 
the body. A study was reported demonstrating the fact that the increase in concentration of $\mathrm{MDA}$ and $8 \mathrm{OHdG}$ has positive correlation with cellular oxidative stress occurrence ${ }^{39}$. Moreover, when DNA damaged occurred, DNA repair is immediately undertaken followed by $8 \mathrm{OHdG}$ production and then excreted into urine in the unchanged form.

The concentration of MDA and 8OHdG in PaM50-7, PaM100-7, and PaM150-7 groups were lower significantly compared to those negative control groups, but higher significantly compared to those of normal group. These results demonstrated that administration of PaM with doses of $50 \mathrm{mg}, 100 \mathrm{mg}$, and $150 \mathrm{mg}$ during 7 days was able to lower MDA and $8 \mathrm{OHdG}$ concentration following UVB radiation. The PaM capability of lowering concentration of MDA and $8 \mathrm{OHdG}$ is attributable to its flavonoids constituent. There are growing evidences that consumption of antioxidant regularly is able to postpone even prevent degenerative diseases including cardiovascular, cancer, Parkinson's Disease (PD) and Alzheimer's dementia, and other age related diseases ${ }^{23,40,41}$. Because of their lower redox potentials, flavonoids are thermodynamically able to reduce highly oxidizing free radicals (redox potentials ranging from 2.13-1.0 V) such as superoxide, peroxyl, alkoxyl, and hydroxyl radicals by hydrogen atom donation ${ }^{23}$. In addition, due to their capacity to chelating metal ions like as iron and copper, etc. flavonoids also capable of inhibiting free radical generation ${ }^{23}$. For instance, quercetin is widely distributed in plants and the second largest proportion flavonol which is known for its iron-chelating and iron-stabilizing properties. Such trace metals bind at specific sites of different rings of flavonoids structures ${ }^{42}$. Moreover, a 3,4 catechol structure in the B ring of flavonoids clearly enhances inhibition of lipid peroxidation. On the other hand, flavones lacking catechol system on oxidation lead to formation of unstable radical exhibit weak scavenging potential ${ }^{43}$. Therefore, catechol structure in flavonoids have pivotal role and make them most effective scavengers of peroxyl, superoxide, and peroxynitrite radicals ${ }^{44}$. For instance, both epicatechin and rutin are strong radical scavengers and inhibitors of lipid peroxidation in vitro ${ }^{23}$. The redox potential (at $\mathrm{pH} 7$ ) of the tocopherol radical/tocopherol is higher than that of the quercetine semiquinone radical/QR couple ${ }^{45}$.
The subclass and type of flavonoids containing in PaM remain unclear, therefore need further study to identify those flavonoids.

Furthermore, concentration of MDA and $8 \mathrm{OHdG}$ in PaM100-15 and PaM150-15, were significantly lower compared to those of PaM50-7, PaM100-7, and PaM150-7 respectively. Concentration of $8 \mathrm{OHdG}$ in PaM150-15 in particular was higher compared to that of normal group, but that difference was not significant. This result confirms to the prior hypothesis that prolong administration of $\mathrm{PaM}$ provides cells an available time to undertake denovo membrane formation and DNA repair. However, considering antioxidant activity of flavonoids can be altered to pro-oxidant activity, therefore specific caution should be paid when flavonoids is administered in the long duration and high dose. Some reports have shown that flavonoids particularly, quercetine aside from posses antioxidant property, also have mutagenic and carcinogenic adverse effect ${ }^{46,47}$ and these effect are attributable to pro-oxidant activity of quercetine due to cathecol or pyrogallol producing free radicals in the presences of metal ion such as $\mathrm{Cu}^{2+25,48}$. Another study reported that administration of quercetine with dose 20 $\mathrm{mg} \mathrm{kg}{ }^{-1}$ body weight and atrazine (a pesticide) with dose $120 \mathrm{mg} \mathrm{kg}^{-1}$ each day simultaneously during 16 days effectively synergize atrazine induced reproductive toxicity ${ }^{49}$. That result is apparently opposite with the result of the present study, since administration of PaM for 15 days was able to decrease the concentration of $8 \mathrm{OhdG}$, possibly caused by the difference type and doses of flavonoids, however it needs further research.

On the other hand, the activity of SOD and CAT in PaM50-7, PaM100-7, and PaM150-7 were significant higher compared to those of Neg-7 and Neg-15, but lower significantly when compared with those of normal group. These results indicated that administration of PaM for seven days was able to increase activities of both SOD and CAT. This finding is in line with numerous reports including in vitro and in vivo studies. Meanwhile, the activity of SOD and CAT among treatment groups: PaM50-7, PaM100-7, and PaM150-7, the highest was PaM150-7. However, when compared with PaM100-15 and PaM150-15, activity of SOD and CAT in PaM50-7, PaM100-7, and PaM150-7 were significant lower respectively (Figure 1). These results demonstrated that PaM administration during 15 days in rats was capable 
of increasing activity of antioxidant SOD and CAT much better rather than 7 days administration. This result was similar with the quercetine administration in mice during 7 days compared with 1 day $^{50}$.

Correlation test between SOD activity and MDA concentration as well as SOD and $8 \mathrm{OHdG}$ with Pearson methods on each group displayed a strong negative correlation $(-0.931$ and $-0.913 ; \mathrm{p}<0.001)$ respectively. Likewise to the CAT activity and MDA concentration as well as CAT activity and $8 \mathrm{OHdG}$ concentration, showed strong negative correlation $(-0.908,-0.889$; $\mathrm{p}<$ 0.001 ) respectively. On the other hand, a strong positive correlation between activity of SOD and CAT also occur $(0.981, \mathrm{p}<0.001)$. Likewise, the strong positive correlation $(0.969 ; \mathrm{p}<0.001)$ also occur between concentration of MDA and 8OHdG (Figure 2). These results suggested that UVB irradiation on rats inducing elevation of MDA concentration invariably followed by increase in $8 \mathrm{OHdG}$ concentration. It is plausible, considering both $\mathrm{MDA}$ and $8 \mathrm{OHdG}$ are generated from the same free radical $\left(\mathrm{OH}^{\circ}\right)$ which is sparked by UVB radiation. Similarly, increase in SOD is invariably followed by an increase in CAT, since SOD is primary enzyme account for dismutation of superoxide to $\mathrm{H}_{2} \mathrm{O}_{2}$. Subsequently, $\mathrm{H}_{2} \mathrm{O}_{2}$ is reduced by CAT to oxygen and water ${ }^{14}$. In contrary, the increase in $\mathrm{MDA}$ and $8 \mathrm{OHd}$ Gconcentration always followed by the decrease in the activity of SOD and CAT or vice versa.

The strong negative correlation between these antioxidants and oxidants are regulated by GSH/GSSG ratio. As either depletion of antioxidants or accumulation of ROS cells attempt to counteract the pro-oxidant effect and restore the redox balance. A study reported that UVB irradiation on cells induced dramatic depletion of GSH and therefore caused a decrease in GSH/GSSG ratio. Quercetine restored the GSH depletion back to control level ${ }^{50}$. The result of the present study was in alignment with the previous studies.

\section{Conclusion}

In conclusion, UVB irradiation repeatedly caused increase in MDA and $8 \mathrm{OHdG}$ concentration and decrease in SOD and CAT activities. PaM administration with $50 \mathrm{mg}, 100 \mathrm{mg}$, and $150 \mathrm{mg}$ during 7-15 days was capable of improving oxidative stress parameters marked by decrease in MDA and 8OHdG concentration and increase in SOD and CAT activities in male Sprague Dawley male rats. There was a negative correlation between oxidant concentration and antioxidant activity. Based upon the result of the present study and considering the majority cause of degenerative disease is oxidative stress; thus reduce oxidative stress with oral antioxidant is a rationale choice. One of the oral antioxidant that available in nature is $\mathrm{PaM}$, an indigenous plant of Indonesia.

\section{Acknowledgements}

The research was supported and funding by Indonesian ministry of high education and research.

\section{Conflicts of Interests}

No conflicts of interest were declared with relation to this work.

\section{References}

1. Abikusno N. Older population in Indonesia: Trends, issues and policy responses. Bangkok: UNFPA Indonesia and Country Technical Services Team for East and SouthEast Asia; 2007 Nov.

2. Noveria M. Challenges of population ageing in Indonesia. Conference on Impact of Ageing: A Common Challenge for Europe and Asia; Vienna. 2006 Jun 7-9.

3. McCarthy M. Boom in Latin American and Caribbean elderly population. The Lancet. 2004; 363:458-9. Crossref.

4. Dobriansky Pj, Suzman RM, Hodes RJ. Why population aging matters: A global perspective. National Institute on Aging National Institutes of Health. US Department of Health and Human Services. US Department of State; 2007.

5. Fries JF. Aging, natural death, and the compression of morbidity. The New England Journal of Medicine. 1980; 303:130-5. Crossref. PMid:7383070

6. Huebschmann AG, Kohrt WM, Regensteiner JG. Exercise attenuates the premature cardiovascular aging effects of type 2 diabetes mellitus. Vascular Medicine. 2011; 16(5):378-90. Crossref. PMid:21893560

7. Hillman CH, Kirk I. Erickson KI, Kramer AF. Be smart, exercise your heart: Exercise effects on brain and cognition. Neuroscience. 2008; 9:52-63. Crossref. 
8. SyslovaK, Bohmova A, Mikoska M, Kuzma M, Pelclova D, KaIer P. Multimarker screening of oxidative stress in aging. Oxidative Medicine and Cellular Longevity. 2014; 1-14. Crossref. PMid:25147595 PMCid:PMC4124763

9. Taufiqurrachman. The effect of buceng extracts on androgen production in Sprague Dawley male rats. Medical Journal of Indonesia. 2012; 21(1):29-31. Crossref.

10. Afaq F, Syed DN, Malik A, Hadi N, Sarfaraz S. Delphinidin, an Anthocyanidin in Pigmented Fruits and Vegetables, Protects Human HaCaT Keratinocytes and Mouse Skin Against UVB Mediated Oxidative Stress and Apoptosis. Journal of Investigative Dermatology. 2007; 127:222-232. Crossref. PMid:16902416

11. Bowden GT. Prevention of non-melanoma skin cancer by targeting ultraviolet-B-light signalling. Nat Rev Cancer. 2004; 4:23-35. Crossref. PMid:14681688

12. Sproul CD, Mitchell DL, Rao S, Ibrahim JG, Kaufmann WK. Cyclobutane pyrimidine dimer density as a predictive biomarker of the biological effects of ultraviolet radiation in normal human fibroblast. Photochemistry and Photobiology. 2014; 90:145-54. Crossref. PMid:24148148 PMCid:PMC4454621

13. Chang $\mathrm{H}$, Oehrl W, Elsner P, Thiele JJ. The role of $\mathrm{H} 2 \mathrm{O} 2$ as a mediator of UVB-induced Apoptosis in Keratinocytes. Free Radical Research. 2003; 37:655-63. Crossref. PMid:12868492

14. Birben E, Sahiner UM, Sackesen C, Erzurum S, Kalayci O. Oxidative stress and antioxidant defense. WAO Journal. 2012; 5:9-19. Crossref.

15. Cadet J, Sage E, Douki T. Ultraviolet radiation-mediated damage to cellular DNA. Mutat Res. 2005; 571:3-17. Crossref. PMid:15748634

16. Budiyanto A, Ahmed NU, Wu A, Bito T, Nikaido O, Osawa $\mathrm{T}$ et al. Protective effect of topically applied olive oil against photocarcino genesis following UVB exposure of mice. Carcinogenesis. 2000; 21:2085-90. Crossref. PMid:11062172

17. Clydesdale GJ, Dandie GW, Muller HK. Ultraviolet light induced injury: Immunological and inflammatory effects. Immunology and Cell Biology. 2001; 79:547-68. Crossref. PMid:11903614

18. De la Fuente M, Miquel J. An update of the oxidationinflammation theory of aging: The involvement of the immunesysteminoxi-inflamm-aging.CurrentPharmaceutical Design. 2009; 15:3003-026. Crossref. PMid:19754376

19. Romano AD, Serviddio G, de Matthaeis A2, Bellanti F, Vendemiale G. Oxidative stress and aging. J Nephrol. 2010; 23(S15):S29-36. PMid:20872368
20. Suzery M, Cahyono B, Taufiqurrachman. Produksi Senyawa Afrodisiakdari Purwoceng (Pimpinella Alpina Molk): Pengembangan Potensi "Natural Resources" Khas Jawa Tengah. Diponegoro University Documentation; 2004.

21. Pandey AK, Mishra AK, Mishra A. Antifungal and antioxidative potential of oil and extracts derived from leaves of Indian spice plant Cinnamomumtamala. Cellular and Molecular Biology. 2012; 58:142-7. PMid:23273204

22. Rahal A, Kumar A, Singh V, Yadav B, Tiwari R, Chakraborty S, Dhama K. Oxidative stress, prooxidants, and antioxidants: The interplay. Bio Med Research International. 2014; 1-19. Crossref. PMid:24587990 PMCid:PMC3920909

23. Kumar S, Pandey AK. Chemistry and biological activities of flavonoids: An overview. The Scientific World Journal. 2013; 1-16. Crossref. PMid:24327805 PMCid:PMC3845396

24. Chen WS, Lee YJ, Yu YC, et al. Enhancement of p53mutant human colorectal cancer cells radio sensitivity by flavonoid fisetin. Int J Radiation Oncology Biol Phys. 2010; 77:1527-35. Crossref. PMid:20637980

25. Cao G, Sofic E, Prior RL. Antioxidant and prooxidant behaviors of flavonoids: Structure activity relationships. Free Radic Biol Med. 1997; 22:749-60. Crossref.

26. Shadnia S, Azizi E, Hosseini R, Khoei S, Fouladdel S, Pajoumand A, Jalali N, Abdollahi M. Evaluation of oxidative stress and genotoxicity in organo phosphorus insecticide formulators. Human and Experimental Toxicology. 2005; 24:439-45. Crossref. PMid:16235732

27. Amaral S, Redmann K, Sanchez V, Mallidis C, Santos JR, Schlatt S. UVB irradiation as a tool to assess ROS-induced damage in human Spermatozoa. Andrology. 2013; 1: 707-14. Crossref. PMid:23836725

28. Erik L. Regalado, Rodríguez M, Menendez R, Angel A, et al. Repair of UVB-damaged skin by the antioxidant sulphated flavone glycoside thalassiolin B isolated from the marine plant thalassiatestudinum banks ex König. Mar Biotechnol. 2009; 11:74-80. Crossref. PMid:18607659

29. Hattori Y, Nishigori C, Tanaka T, Uchida K, Nikaido $\mathrm{O}$, et al. 8-hydroxy-2'-deoxyguanosme is increased in epidermal cells of hairless mice after chronic ultraviolet B exposure. J Invest Dermatol. 1997; 107:733-7. Crossref.

30. Halliwell B, Aruoma OI. DNA and free radicals. Chichester, UK: Ellis Horwood; 1993.

31. Clarkson PM and Thompson HS. Antioxidants: what role do they play in physical activity and health? Am J ClinNutr. 2000; 72(suppl):637S-46S. Crossref. PMid:10919970 
32. Santos AL, Oliveira V, Baptista I, Henriques I, Gomes NCM, et al. (2013) Wavelength dependence of biological damage induced by UV radiation on bacteria. Arch Microbiol 2013; 195:63-74. Crossref. PMid:23090570

33. Zhan JYX, Wang XF, Liu YH, Zhang ZB, Wang L et al. Andrographolide sodium bisulfate prevents UV-induced skin photoaging through inhibiting oxidative stress and inflammation. Mediators of Inflammation. 2016; 1-12. Crossref. PMid:26903706 PMCid:PMC4745921

34. Cejkova J, Stipek S, Crkovska J, Ardan T. Changes of superoxide dismutase, catalase and glutathione peroxidase in the corneal epithelium after UVB rays. Histochemicaland biochemical study. Histol Histopathol. 2000; 15:1043-50. PMid:11005228

35. Yin Y, Li W, Son YO, Sun L, Lu J, et al. Quercitrin protects skin from UVB-induced oxidative damage. Toxicol Appl Pharmacol. 2013; 269(2):89-9. Crossref. PMid:23545178 PMCid:PMC3700335

36. Dalton TP, Shertzer HG, Puga A. Regulation of gene expression by reactive oxygen. Ann Rev Pharmacol Toxicol. 1999; 39:67-101. Crossref. PMid:10331077

37. Okada K. Takahashi Y. Ohnishi K. Isliikawa O, Miyachi Y. Time dependent effect of chronic UV irradiation on superoxide dismutase and catalase activity in hairless mice skin. J Deiinalol Sci. 1994; 8:183-6. Crossref.

38. Gul MZ, Ahmad F, Kondapi AK, Qureshi IA, Ghazi IA. Antioxidant and antiproliferative activities of Abrusprecatorius leaf extracts - an in vitro study. BMC Complementary and Alternative Medicine. 2013; 13:53. Crossref. PMid:23452983 PMCid:PMC3600005

39. Fukushima K, Murata M, Tsukimori K, Eisuke K, Wake N. 8-hydroxy-2-deoxyguanosine staining in placenta is associated with maternal serum uric acid levels and gestational age at diagnosis in pre-eclampsia. American Journal of Hypertension. 2011; 24(7):829-33. Crossref. PMid:21415844

40. Zern TL, Fernandez ML. Cardioprotective effects of dietary polyphenols. J Nutr. 2005; 135:2291-4. Crossref. PMid:16177184

41. Giovannini C, Masella R. Role of polyphenols in cell death control. Nutritional Neuroscience. 2012; 15(3):134-9. Crossref. PMid:22584012
42. Van A, van den Berg SABE, Tromp DJMNJL et al. Structural aspects of antioxidant activity of flavonoids. Free Radical Biology and Medicine. 1996; 20(3):331-42. Crossref.

43. Pannala AS, Chan TS, Brien PJO, Rice Evans CA. Flavonoid B-ring chemistry and antioxidant activity: Fast reaction kinetics. Biochemical and Biophysical Research Communications. 2001; 282(5):1161-8. Crossref. PMid:11302737

44. Kelly EH, R. Anthony T, Dennis JB. Flavonoid antioxidants: Chemistry, metabolism and structureactivity relationships. Journal of Nutritional Biochemistry. 2002; 13(10):572-84. Crossref.

45. Bakir T, Sonmezoglu I, Imer F, Apak RS. Antioxidant/ prooxidant effects of a-tocopherol, quercetin and isorhamnetin on linoleic acid peroxidation induced by $\mathrm{Cu}(\mathrm{II})$ and H2O2. Int J Food Sci Nutr. 2014; 65(2):226-34. Crossref. PMid:24152374

46. Blessing EO, Francis M. Dose-related effect of quercetin in the human breast carcinoma MCF-7 cell line. American Journal of Scientific and industrial research. Science. 2010. Available from: Crossref.

47. Resende FA, Vilegas W, Santos LC, Varanda EA. Mutagenicity of flavonoids assayed by bacterial reverse (Ames) test. Molecules. 2012; 17:5255-68. Crossref. PMid:22565478

48. Sghaier MB, Skandrani I, Nasr N, Franca MGD, Ghedira LC, Ghedira K. Flavonoids and sesquiterpenes from Tecuriumramosissimum promote antiproliferation of human cancer cells andenhance antioxidant activity: A structure-activity relationship study. Environmental Toxicology and Pharmacology. 2011; 32:336-48. Crossref. PMid:22004952

49. Farombi EO, Abarikwu SO, Adesiyan AC, Oyejola TO. Quercetin exacerbates the effects of subacute treatment of atrazine on reproductive tissue antioxidant defence system, lipid peroxidation and sperm quality in rats. Andrologia. 2013; 45:256-65. Crossref. PMid:22897171

50. Yin Y, Li W, Son YO, Sun L, Lu J, et al. Quercitrin protects skin from UVB-induced oxidative damage. Toxicol Appl Pharmacol. 2013; 269(2):89-99. Crossref. PMid:23545178 PMCid:PMC3700335 